\title{
CONTRIBUTIONS FROM THE ROCKY MOUNTAIN HERBARIUM. XIII
}

\author{
AVEN NELSON
}

[In this paper are brought together a number of interesting species representing various localities. Among the hundreds of specimens submitted to the Rocky Mountain Herbarium each year for verification or identification, a few real novelties invariably appear. The writer wishes to express his appreciation of the fact that many well known botanists, as well as amateurs, cordially permit him to share with them the pleasure of studying their collections, in whole or in part. The names of those who are represented in this paper occur in the notes on the species described. I want to call attention to the fact that two genera, new to Colorado, are included in the list below.]

Brodiaea Paysonii, n. sp.-The membranes sheathing the corms brown and very fibrous, the inner ones prolonged into scarious sheaths $4^{-8 \mathrm{~cm}}$. long and enclosing the base of the glabrous green scapes and leaves: scapes $15^{-25} \mathrm{~cm}$. high: leaves narrowly linear, at least a half longer than the scapes, rather lax and spreading: umbel few-flowered, the pedicels Io- $15 \mathrm{~mm}$. long: bracts ovatelanceolate, acute, scarious and somewhat petaloid, green-nerved, shorter than fully developed pedicels: perianth white, shading to faint rose-color, $15^{-20} \mathrm{~mm}$. long; the oblong obtuse segments a little longer than the tube, delicate in texture with a rather strong purplish-green mid-nerve terminating in a blunt hoodlike tooth at apex: stamens 6 , in one row, united to each other and to the perianth segments by a delicate transparent membrane: anthers large, 5-6 mm. long: ovary ovate-oblong, about 6 ovules in each cell: mature seeds black, very large and thin, $7-8 \mathrm{~mm}$. broad, the body of the seed less than half as wide as the black membranous epicarp.

Named in honor of EDwIN E. PAYson, the collector, an enthusiastic student of the Colorado flora in the Montrose High School, class of I $^{1} \mathrm{I}_{3}$. He reports this plant abundant on the dry adobe soils, blossoming so early that "by the last of June there is nothing showing above ground except the scape bearing the large triangular dehiscent capsule." Payson's no. 33, Montrose, May $18, I_{12} 2$, is the type. 
Eriogonum Visheri, n. sp.-Bushy branched, glabrous or glabrate annual, $15^{-25} \mathrm{~cm}$. high: stem usually solitary from the crown, branching from the first node, the 2 or 3 branches each branching di- or trichotomously several times, the ultimate branchlets filiform: leaves rosulate at the base, a whorl of fewer and smaller leaves at the first node; blades mostly broadly oval, rather thick, $15^{-20} \mathrm{~mm}$. long, on petioles either longer or shorter than the blades; involucres turbinate, in the forks or at the nodes, either sessile or on slender erect pedicels $5^{-10} \mathrm{~mm}$. or more long: flowers solitary or few in each involucre, usually drooping on short pedicels, very small, yellow; the perianth segments narrowly oblong, I-I.5 mm. long: achene trigonous, ovoid-acuminate, $2 \mathrm{~mm}$. long.

Singularly like E. mohavense Wats. in general aspect, but at once separate by its glabrous leaves. Geographically and environmentally very different. Secured by Professor S. S. VISHER, of the State. University of South Dakota at Meadow, Perkins County, August 3, 1912, no. 536.

Polygonum pannosum S. S. Sharp, ${ }^{\mathrm{I}}$ n. sp.-Slender, glabrous annual, I $5^{-25} \mathrm{~cm}$. high, from a slender, rigid taproot: stem branching irregularly from near the base upward, giving the plant a bushy appearance: leaves few, linear, inclined to be revolute, I-I. $5 \mathrm{~cm}$. long, acute, sessile, becoming bractlike above; sheaths lacerate into numerous threadlike awns, scarious on the margin, but with a brown midrib extending from the base to about one-half their length: flowers numerous in long, slender, spicate racemes, often secund, usually two in the axil of each small, subulate bract, both not appearing at the same time or one remaining rudimentary; pedicels short, slender, but slightly exserted, gradually curved downward until the mature flowers and fruits are deflexed: perianth segments white or sometimes pinkish, with a green midrib and base, $4 \mathrm{~mm}$. long: stamens 8 : style short, the branches slightly spreading: achene black, smooth and shining, triquetrous, broadly ovoid, $2-3 \mathrm{~mm}$. long.

Most nearly allied to $P$. Douglasii Greene, but at once seen to be different by the slender zigzag skeletonized stems, the minute linear leaves, and the lacerate sheaths. It was found on sandy slopes in the hills near Sheridan,
Wyoming, August 26, I9I $_{2}$, my no. 258 .

${ }^{x} \mathrm{Mr}$. SHARP is a student in the University of Wyoming. 
Atriplex Greenei, n. sp.-Pale greenish moderately scurfy annual, with tapering taproot $\mathrm{I} \mathrm{dm}$. or more long, branching from the crown: the axes of the main branches excurrent, $x \cdot 5-3 \mathrm{dm}$. long, somewhat tortuous or zigzag, with short slender spreading or ascending branchlets from the numerous approximate nodes: leaves very narrowly linear, the lower only ro-1 $5 \mathrm{~mm}$. long, passing into the subulate bracts above: fructiferous throughout, the fertile flowers I-several at each node: fruiting bracts very small, about $2 \mathrm{~mm}$. long, closely united, narrowly ovate, the obtuse apex often tipped with a small tooth, the backs usually appendaged at the middle or above with few-several small conical or cylindrical papillae.

This species is most nearly allied to A. tenuissima A. Nels., Bor. GAZ. $34: 257.1902$, but in that the leaves are only $1 \rightarrow 7 \mathrm{~mm}$. long, oblong to ovate or broader, and the fruit subpyramidal and tuberculate below the middle.

I dedicate this species to its collector, the indefatigable phytographer, philosopher, and historian, my friend, Dr. E. L. GREENE, who secured it at Rock Springs, Wyoming, August 9, r8g6.

Arceuthobium Blumeri, n. sp.-Stems branching dichotomously beginning at the first node and then either regularly or often skipping a node, $4-8 \mathrm{~cm}$. long: fertile branches pale-green, with sharply almost wing-angled internodes; the connate scales forming a shallow cup with two very short broadly triangular points (or these sometimes nearly or quite wanting), the cup about $2 \mathrm{~mm}$. broad: fruit narrowly elliptic or almost fusiform, $3 \mathrm{~mm}$. long and half as broad, on a stipe about $2 \mathrm{~mm}$. long, the body blue-green, the wrinkled conical apex and the stipe pale.-On Pinus strobiformis Engelm.

Specimens on which this species is based were secured in the Huachuca Mountains of Arizona, in October I9ro, and were communicated by J. C. BLUMER. Apparently this is the first record of this genus on the above species of five-leaved pines. A. cyanocarpum has been reported only on Pinus flexilis James. A. divaricatum Engelm. seems to use the one and two-leaved pines as host.

Astragalus macer, n. sp.-Pale and obscurely appressed puberulent: caudex branched, mostly subterranean: stems slender, sparingly branched, $3-5 \mathrm{dm}$. high, including the raceme: leaves with linear rachis $3^{-6} \mathrm{~cm}$. long, on which are borne $3-7$ linear alternate 
or subopposite pinnae $5^{-10} \mathrm{~mm}$. long; stipules linear-subulate: flowers not in condition but evidently pale or ochroleucous: calyx tube narrowly campanulate, $5 \mathrm{~mm}$. long, the subulate teeth half as long: pod glabrous, strictly I-celled, dorsiventrally flattened, somewhat keeled by both sutures, linear-oblong, acute at both ends, 20-30 $\mathrm{mm}$. long, 3-4 $\mathrm{mm}$. broad; stipe from scarcely longer to twice as long as the calyx tube: ovules about io, the alternate ones apparently aborting; seeds flat, nearly as broad as the pods.

Allied to A. lonchocarpus Gray, from which it is at once distinct by its solid (not fistulous), slender stem, its smaller flattened pod on a much shorter stipe. Secured by E. P. WALKER ${ }^{2}$ on dry foothills, Paradox Valley, Colorado, June 24, I9I 2.

Viola Sheltonir biternata, n. comb.- V. biternata, Greene, Pl. Baker. 3:12. I901; V. Sheltonii Rydb., Fl. Col., not Torr. Mr. Payson's specimens make it evident that a form of the far western
m. Sheltonii does occur in the Rocky Mountains. While it is not strongly marked, it would seem best to keep it as a geographical variety.

Chylisma Walkeri, n. sp.-Very slender annual I-2 dm. high, including the fruiting raceme which is more than half the plant: stem simple, or sparingly branched above, minutely glandularpuberulent and with some long white scattering spreading hairs: leaves few, approximate just below the peduncle or penduncular branches, entire, ovate to oblong-lanceolate, somewhat shaggy with stiffish white hairs: pedicels filiform, in fruit Io-14 mm. long, spreading at right angles (or somewhat deflexed), and bearing the ascending or erect capsule candelabra-like on the assurgent tip, subtended by a small, ovate, hirsute bract: flowers minute (for this genus), only $2 \mathrm{~mm}$. long, yellow: calyx tube $0.5 \mathrm{~mm}$. long, narrowly oval, petals broadly oval: capsules large for the plant, clavate, as long as the pedicels: seeds large, lance-oblong.

Probably allied to C. scapoidea (Nutt.) Small, and to C. Parryi (Wats.) small flowers, the latter in every way suggesting one of the small-flowered
species of Sphaerostigma.

E. P. WaLKer's no. 200, Paradox Valley, Colorado, July I, I9I 2, is the type and was secured on dry "gyp" hills. ${ }^{2} \mathrm{Mr}$. WALKER collected quite extensively for the University of Wyoming, in the
vicinity of his home, Paradox Valley, southwestern Colorado, during the season of 1912. 
Azaleastrum Warrenii, n. sp.-A low stoutish shrub, with grayish bark, the youngest twigs brown or greenish-brown: leaves in terminal fascicles of $3-5$, ovate, oval, or obovate, from broadly rounded at apex to subacute, thin, green on both sides, glabrate (even when young), closely studded on the margin with minute gland-tipped hairs, the blade $\mathrm{I}-2 \mathrm{~cm}$. long and tapering to the short margined petiole-like base: the leaf bud scales (stipules?) oblong-lanceolate, hirsute with reddish-brown hairs: flower buds with similar reddish-brown hairs but these very few and scattering on the oval brown deciduous scales, on the short stoutish glandular peduncle, and on the backs of the sepals: flowers lateral on the young twigs, solitary or few at the approximated nodes: sepals narrowly obovate-elliptic, same texture and color as the leaves, 7-10 $\mathrm{mm}$. long, obtuse or obtusish, closely beaded on the margin and back with short gland-tipped hairs: corolla campanulaterotate, IO-I5 $\mathrm{mm}$. long and broad; its lobes suborbicular, about as long as the tube: stamens Io; the cells opening by terminal pores; the stoutish filaments shorter than the corolla, softly pubescent below the middle only: pistil stoutish, obscurely pubescent near the base, enlarging upward to the peltate-capitate stigma, the five lobes of which are encircled by a ringlike border: ovary covered with the gland-tipped hairs characterizing the plant: fruit wanting, but the ovules very numerous on the columellar placenta.

This very interesting Rhododendron ally was secured by Mr. EDwaRd R. WARREN, of Colorado Springs, so well known for his "Mammals of Colorado," July 14, I9II, in Jackson County, Colorado. The material was exceedingly meager, but the request for full notes brought a very interesting letter, from which the following paragraph is quoted:

"What you say about my no. I6 is very interesting. I found it at my camp on the lower slope of Mt. Zirkel, at the head of navigation for prairie schooners on the 'Ute Pass Trail.' If I remember correctly, it was quite abundant. It was a low plant, perhaps not more than a foot high. It was growing on a slope which was free from growing green timber, with many fallen dead logs, and some standing dead stubs. Soil was gravelly. I made the altitude 9,275 feet, and my altitudes checked very well last summer. There were a few scattering aspens growing about. I may possibly be mistaken as to its being a low plant, I made no special notes, but it was a different growing plant from the Ceanothus which grew in the region, and not as conspicuous a shrub. I evidently did not collect much of it, for I have but a single 
twig left, and am sending you about half the flowers and leaves from it. If it turns out new and you wish to describe it now, I can send you the rest to be deposited as type specimen. It has quite a woody stem."

Its far northern relative Rhododendron albiflorum Hook. was raised to generic rank by Dr. RydBeRg in his Flora of Montana, apparently very properly, using the name of the section in which it had been the sole species.

Gentiana polyantha, n. sp.-Glabrous annual, 3-6 dm. high, erect, consisting of a main axis and usually a pair of slender erect floriferous branches from each of the several-many nodes: leaves numerous, nearly all subtending cymose flower clusters; lower leaves oblanceolate, nearly sessile by a broadish base, $2-3 \mathrm{~cm}$. long; middle stem leaves sessile, somewhat longer, from oblong to lanceolate; gradually passing into linear-lanceolate ones with broad base: the thyrsiform inflorescence often extending nearly to the base of the plant: calyx with 2 ovate-lanceolate foliaceous sepals as long as the corolla tube, and 3 much smaller somewhat unequal nearly linear lobes: corolla blue or purplish; its tube IO-I $3 \mathrm{~mm}$. long; its ovate lobes about $5 \mathrm{~mm}$. long, a broad laceratesetaceous scale fully half as long at the base of each.

In floral characters this is singularly like $G$. heterosepala Engelm., but there the similarity ends. As compared with that, the proposed species is unique
in the longer acute leaves, many flowered thyrse (some the numerous branches and short internodes, the pedicels. Secured by ERNEST P. With more than roo flowers), and the short August 2I, IgI 2 .

Gentiana Andrewsin dakotica, n. var.-Leaves smaller and more numerous, narrowly oblong, $4-6 \mathrm{~cm}$. long, tapering gradually to both base and apex, obtusish: corolla smaller, less dilated near the middle: stamens shorter, the scarcely adherent anthers extending
but little above the middle of the corolla: corolla truncate at the barely contracted orifice, slightly lacerate-dentate on the margin. Anyone looking over a series of specimens representing $G$. Andrewsii will
be struck at once by the marked difference in aspect between the eastern
ones and those from the Dakotate fruit characters are examined $G$. So marked is this that until the flora and plants. The differences, however, do not is not suggested by the Dakota well be designated by a varietal do not seem to be fundamental, but may secured by Professor TuFTet name. The finest example at hand is one Lake, August I 5, I9II, no. I95. 
Mertensia refracta, n. sp.-Obscurely appressed pubescent throughout, the minute hairs without pustulate base: stems tufted, rather stout, more or less branched above, $2-4 \mathrm{dm}$. high (including the ample inflorescence), rather densely and equably leafy except below where the leaves are smaller or wanting: leaves sessile or nearly so, oblong to ovate, obtuse or subacute, $3-5 \mathrm{~cm}$. long, 8-r4 mm. broad: pedicels slender, 6-ro mm. long, early reflexed and most of them ultimately refracted: calyx cleft to the base; its lobes linear, softly hirsute, $2-3 \mathrm{~mm}$. long: corolla blue, I cm. long; the campanulate throat and limb as long as the broad tube: stamens inserted in the throat; the filaments scarcely as broad as the anthers: crests inconspicuous: style almost as long as the corolla.

The most striking character of this species is the refracting of the pedicels, much as in certain species of Lappula, a character I do not recall as occurring in other species of Mertensia. In some species some of the flowers are at length reflexed, and in most of them the inflorescence as a whole is more or less drooping, but in this one the individual pedicels are sharply refracted at their very base.

Secured by A. A. Griffrin, Wagon Wheel Gap, Colorado, at 9000 feet, July 28 , I $19 \mathrm{I}_{2}$, no. $\mathrm{I} 39$.

Oreocarya paradoxa, n. sp.-Matted cespitose perennial; the caudex freely branched, the branches short, crowded, covered with dead leaf-bases: stems short, $8-\mathrm{I}_{5} \mathrm{~cm}$. long, more or less curved and ascending from the decumbent base, hirsute-hispid: leaves numerous, spatulate-oblanceolate, I. $5-3 \mathrm{~cm}$. long, including the narrowed petiole-like base, subhispid with more or less appressed white hairs: inflorescence at first subcapitate, becoming a short thyrsoid spike: calyx cleft to the base, its lobes linearlanceolate, 4-5 mm. long: corolla tube yellow, slender, nearly three times as long as the sepals; the yellowish or nearly white corolla lobes obovate, fully one-third as long as the tube; the crests very prominent: anthers just below the crests: nutlets ovoid, muriculate, attached by the middle to the ovoid gynobase, the free portion of the style twice as long as the mature nutlets.

The yellow-flowered species of Oreocarya are not numerous, and the long-flowered ones are even scarcer. This strongly tufted-matted form with its long clear-yellow tube is distinctive. Secured by E. P. WALKER on dry "gyp" hills, in Paradox Valley, Colorado, no. 9I, June I9, I9I 2. 
Pentstemon Griffinii, n. sp.- Stems solitary from the crowns of the short slender branches of the subterranean caudex, very slender, glabrous, erect, ${ }^{2-} 3 \mathrm{dm}$. high: basal leaves rosulate on the crowns, relatively few, oblong-oblanceolate, I. $5^{-3} \mathrm{~cm}$. long, tapering into very short petioles; stem leaves about 3 pairs, those of the lowest linear-spatulate, the others linear and smaller: flowers few, in an open obscurely glandular-pubescent cymose panicle with subulate bracts: sepals ovate, acute, often purplish, with scarious margins, $5^{-7} \mathrm{~mm}$. long: corolla bluish-purple, tubular-funnel-form, about $2 \mathrm{~cm}$. long, the lips unequal; lower lip with two longitudinal yellow-bearded crests: sterile filament densely bearded for more than half its length with short soft yellow hair; anthers cells confluent but not explanate.

No very near ally of this is known to the writer. Collected by ALFred A. GrIfFIN in the Rio Grande Valley, on moist east slopes, at 8200 feet, July 28 , I9I 2, no. I45. Mr. GRIFFIN, who is now at the University of Michigan, is connected with the National Forest Service and was in the field in Colorado in the summer of 1912 .

Machaeranthera pUlverulenta vacans, n. var.-Probably a short-lived perennial, greenish, the viscosity extending to the branches and stems: stems suberect and sparingly branched: leaves small, mostly linear.

It seems rather superfluous to add new names to our already long list, but the following numbers from WALKER's collections are so aberrant that one hesitates to refer them to a known species without some explanation: no. 360 , Paradox, August i; no. 537, Coventry, Sept. 2; no. 434 (less typical),
San Miguel Canon, August Io, I9I 2 .

Wyomingia vivax, n. sp.-The shrubby base (caudex) naked, freely branched, $5^{-10} \mathrm{~cm}$. high; the season's stems very slender, simple, moderately cinereous, $3-6 \mathrm{dm}$. high: leaves closely appressedcinereous, scattering on the crowns of the caudex and on the stems, linear or some of them narrowly spatulate, $2-4 \mathrm{~cm}$. long, becoming smaller upward and passing into the small bracts of the inflorescence: heads few-several, in an open corymb, medium size; involucre hemispheric, 7 -10 $\mathrm{mm}$. broad, its bracts softly cinereous, in 3 or 4 unequal rows; rays ${ }_{5}-20$, pink; disk flowers numerous, small, with sordid pappus shorter than the corolla; achene sparsely pubescent, shorter than the pappus. 
The generic position of this plant is not clear. It is aberrant as a Wyomingia, but more so as an Erigeron or Aster. It was secured by E. P. WALKER on the east slope of the La Sal Mountains, Utah, at about 9000 feet elevation. Dry rocky hills, July 30, I9I 2, no. 355 .

Taraxacum fasciculatum, n. sp.- Root slender, with an enlarged crown bearing few-several oblanceolate or oblong obtusish merely dentate or denticulate subsessile or short-petioled glabrous leaves 4-7 cm. long: scapes in small fascicles of 2-several (usually 3 or 4 ) from the crown, produced simultaneously and subequal in length, in full flower I $2-14 \mathrm{~cm}$. long: heads medium size, the short calyculate bracts few or wanting, none reflexed; involucral bracts, I $2-14 \mathrm{~mm}$. long, lanceolate to linear, the outer ones notably corniculate (achenes immature in the specimens at hand).

A remarkably fine native species, seemingly very distinct. A. A. GRIFrin, no. I I I, Wagon Wheel Gap, Blue Park, altitude II,000 feet, July 2I, I9I 2.

Rocky Mountain Herbarium

LARAMIE, WYOMING 


\section{$2 \mathrm{BHL}$ Biodiversity Heritage Library}

Nelson, Aven. 1913. "Contributions from the Rocky Mountain Herbarium. XIII." Botanical gazette 56(1), 63-71. https://doi.org/10.1086/331107.

View This Item Online: https://www.biodiversitylibrary.org/item/39605

DOI: https://doi.org/10.1086/331107

Permalink: https://www.biodiversitylibrary.org/partpdf/223519

\section{Holding Institution}

Missouri Botanical Garden, Peter H. Raven Library

\section{Sponsored by}

Missouri Botanical Garden

\section{Copyright \& Reuse}

Copyright Status: Public domain. The BHL considers that this work is no longer under copyright protection.

This document was created from content at the Biodiversity Heritage Library, the world's largest open access digital library for biodiversity literature and archives. Visit BHL at https://www.biodiversitylibrary.org. 